\title{
A JURISDIÇÃO ILUSÓRIA EM PRIMEIRA INSTÂNCIA: CRÍTICA DOS PRESSUPOSTOS IDEOLÓGICOS DO SISTEMA RECURSAL BRASILEIRO
}

\section{THE ILLUSTRATIVE JURISDICTION AT FIRST INSTANCE: CRITICISM OF THE IDEOLOGICAL ASSUMPTIONS OF THE BRAZILIAN RESOURCES SYSTEM}

\section{RESUMO}

O presente artigo, inspirado nas ideias de Ovídio A. Baptista da Silva, objetiva expor como a complexidade do sistema recursal brasileiro influencia para o descrédito da atividade jurisdicional em primeira instância, afastando a solução dos conflitos da realidade fática que os gerou e tornando a prestação jurisdicional morosa e carente de efetividade.

Palavras-Chaves: Confiança. Sistema Recursal. Efetividade.

\begin{abstract}
This article, which is inspired on the ideas of Ovídio A. Baptista da Silva, aims to expose how the complexity of the Brazilian appeal system influences to the discredit of judicial activity in the first instance, removing the solution of conflicts from the objective reality which generated them,turning adjudication into a slow and ineffective activity.
\end{abstract}

Keywords: Trust. Appeals System. Effectiveness.

\footnotetext{
${ }^{1}$ Mestre em Direito pela Universidade Federal do Pará - UFPA (2011). Coordenador do Núcleo de Prática Jurídica do Centro Universitário do Pará - CESUPA, Pará (Brasil). Membro da Associação Norte e Nordeste de Professores de Processo. E-mail: arthurlaercio@ hotmail.com

2 Doutor em Direito pela Universidade Federal do Pará - UFPA, Pará (Brasil). Professor de Introdução ao estudo do direito e filosofia do direito do Centro Universitário do Pará (CESUPA). E-mail: ricardoadt@gmail.com
} 


\section{INTRODUÇÃO}

O objetivo da presente pesquisa é questionar, à luz do pensamento do processualista brasileiro Ovídio Baptista, alguns dos pressupostos que sustentam o sistema recursal brasileiro. Mais especificamente, a questão central será referente à maneira como a concepção positivista de decisão correta, bastante ligada a um pressuposto de aplicação como repetição de um sentido unívoco ${ }^{3}$ da lei, acaba causando uma multiplicação excessiva dos recursos cabíveis e esvaziando o papel do juiz de primeiro grau.

Em sua obra Processo e Ideologia (SILVA, 2004) Baptista faz um apanhado histórico a respeito do modo como as revoluções burguesas e a racionalização do direito constituem a concepção de processo como um caminhar para um sentido supostamente unívoco de aplicação do direito, cuja busca e proteção justifica os incontáveis recursos, vistos como necessários para corrigir as interpretações discrepantes, que obviamente, do ponto de um positivismo exegético ${ }^{4}$, são vistas como distorções.

Nesse sentido, buscar-se-á mostrar que, em que pese a importância da noção de reexame das decisões em consideração à falibilidade humana, tal sistema acaba por esvaziar a importância da decisão do juiz de primeiro grau, esfacelando a relevância justamente daquela ou daquele que tem o contato mais imediato com a causa, com os elementos concretos que ali estão em jogo.

Se o contato do juiz de $1^{\circ}$ grau com a causa é fundamental para a concretização dos direitos ali envolvidos, a diminuição de sua importância acaba levando justamente a um sistema que, buscando evitar toda e qualquer falha, deixa os direitos das partes envolvidas quase que em segundo plano.

É de conhecimento geral que o sistema recursal brasileiro é complexo. Mesmo para os juristas mais experientes, conhecer e compreender todo o arcabouço recursal existente no Brasil não é tarefa das mais simples. Do Código de Processo Civil à legislação extravagante,

\footnotetext{
${ }^{3}$ Nesse sentido, é sintomático que apenas nos últimos anos a distinção entre texto normativo e norma como produto da interpretação dos textos tenha passado a constituir o arcabouço teórico da teoria processual brasileira.

${ }^{4}$ Chama-se positivismo exegético à concepção segundo a qual os textos normativos possuem uma única leitura correta, e precisam ser interpretados literalmente. O termo exegético vem de exegese bíblica, isto é, método de leitura literal defendido pelos luteranos em face da tradição católica, que defendia a compreensão bíblica por intermédio dos dogmas da igreja (GADAMER, 1999). Assim, fazer exegese passou a significar ler algo sem subterfúgio de interpretações metafóricas, atribuindo aos relatos o sentido mais literal possível.
} 
as possibilidades recursais são muitas, o que dificulta a compreensão do sistema, ao tempo que possibilita que quase todas as decisões sejam passíveis de impugnação.

Outro fator indiscutível é que um recurso, seja ele qual for, prolonga a prestação jurisdicional. Esse prolongamento, diante do risco de decisões injustas ou falhas do ponto de vista processual, é justificado de várias maneiras. Se é verdade que o prolongamento existe, também é verdade que muitas vezes ele é necessário, pois é normal que a decisão judicial não satisfaça alguém, e por isso possa ser revista por outros juízes, de modo a buscar a tutela mais justa possível para cada caso.

O princípio do duplo grau de jurisdição estabelece um marco normativo segundo o qual toda pessoa que se sinta insatisfeita com uma decisão judicial que interfira em sua esfera de direitos e obrigações possa apresentar sua insurgência contra essa decisão, de modo a anulá-la, modificá-la ou mesmo aprimorá-la, salvo em hipóteses específicas de limitação das possibilidades recursais, como as contidas no art. 1.015 do CPC, relativas ao recurso de agravo de instrumento.

Por regra, a maioria dos processos judiciais tem início parente um juiz singular, exercendo a primeira instância de jurisdição, e avança pelo sistema recursal passando a outros juízes, que em análise isolada ${ }^{5}$ ou colegiada decidirão novamente a questão, podendo-se avançar ainda mais dentro do próprio tribunal — de acordo com o modo como o recurso foi julgado - ou aos tribunais superiores, por meio de Recurso Especial (105, III, CF) ou Extraordinário (102, III, CF), em virtude da matéria decidida.

Quanto mais se avança na seara recursal, mais haverá um afastamento dos julgadores em relação à realidade dos fatos apresentados no caso concreto. É que o juiz de primeiro grau é o responsável pela instrução do processo. Ele terá obrigatoriamente que determinar a produção de provas, ter contato pessoal com as partes, com os advogados e outros sujeitos que regularmente intervêm no processo.

Nos tribunais mais avançados, o contato dos juízes com a causa muitas vezes é “de papel", ou seja, tomam conhecimento dos fatos que deram ensejo à lide por meio dos elementos que lhes foram fornecidos pelas instâncias inferiores, em sua maioria sob a supervisão do juiz singular, de quem justamente se impugna a decisão.

\footnotetext{
${ }^{5}$ É o caso das decisões monocráticas do relator do recurso, previstas especialmente no art. 932 do CPC, que lhe confere o poder de, nos casos em que especifica, julgar um recurso sem a necessidade de levar a resignação ao órgão colegiado.
} 
Diante desses fatos, o que se percebe é que, dada a ampla possibilidade recursal existente no Brasil, muitas vezes a decisão do juiz singular, que justamente teve maior contato com os fatos do processo, tem um peso muito pequeno na solução da causa, tornando-se, em muitos casos, meramente consultiva. E mais: a decisão final — provinda de um tribunal superior - embora advinda de juízes mais experientes, muitas vezes é tomada sem qualquer conhecimento do contexto fático em que a demanda estava inserida.

Nesses termos, unindo Ovídio A. Baptista da Silva em diálogo com outras fontes doutrinárias do direito processual, esse trabalho defenderá a inevitável percepção de como o sistema recursal brasileiro influencia para o descrédito da atividade jurisdicional em primeira instância. A oportunidade de debater as ideias de Ovídio serve não apenas para prestarlhe homenagem, mas para demonstrar o impacto que seus pensamentos tiveram e ainda terão para influenciar o Direito Processual Civil em nosso país.

\section{FUNDAMENTO POLÍTICO-IDEOLÓGICO DO SISTEMA RECURSAL BRASILEIRO}

Investigar os fundamentos político-ideológicos de um sistema jurídico não é tarefa simples. A dificuldade aparece não apenas na medida em que a investigação pressupõe uma base histórica e política, mas também porque o estudo moderno do direito é construído justamente para passar uma imagem de separação radical entre o político e o jurídico, como se os conceitos e os meios de operacionalização do direito pudessem ser conhecidos e manejados independente dos pressupostos políticos que lhe servem de base. (UNGER, 1986).

Assim, as escolhas políticas ficam não apenas eclipsadas pelas discussões técnicas, mas são propositalmente afastadas por uma visão que, baseada nos pressupostos positivistas, considera o estudo das normas jurídicas como uma empresa autônoma (KELSEN, 1998) em relação ao seu fundamento e aos elementos valorativos que corroboraram em sua construção.

Tal visão, eu durante boa parte do século XX fora assumida como obvia nas faculdades de direito e mesmo nos tribunais, pressupunha que existe uma distinção radical entre os elementos políticos que influenciaram nos debates a respeito da criação das normas jurídicas e estas como produto daquelas deliberações. Assim, as normas possuiriam uma existência autônoma, que poderia ser conhecida sem nenhuma consideração de ordem política, sociológica ou histórica a respeito de seu surgimento. Somente nesse sentido é que se poderia falar em autonomia da ciência do direito (KELSEN, 1998). 
Tal visão, como se sabe, começa a perder influência a partir da segunda metade do século $\mathrm{XX}$, quando os elementos histórico-culturais e políticos que constituem o pano de fundo das normas passa a ser trazido à tona como um elemento necessário não apenas para uma crítica moral do direito, mas também como substrato fundamental à própria interpretação e aplicação das normas jurídicas.

Nessa linha crítica, o presente estudo, na esteira de Baptista, implica desvelar os pressupostos velados pela cultura dogmática e questionar o direito por meio de um olhar que avance para além da superfície e atinja seus pressupostos recônditos.

Qualquer sistema recursal é embasado em opções político-legislativas que estabelecem a quantidade de recursos dispostos, as matérias neles veiculadas e os tipos de decisões que serão alvo desses recursos. Embora a formação positivista e excessivamente dogmática dos cursos de Direito por vezes obscureça tal aspecto e concentre o estudo apenas no direito já posto, velando as escolhas políticas que lhe subjazem, tal investigação é imprescindível a uma compreensão mais ampla do sistema jurídico e, nesse caso, do sistema recursal.

O caminho para investigar tais pressupostos deve iniciar não pelo código ou pelas leis extravagantes, mas obviamente pela Constituição, pois é na Carta Magna que são estabelecidas, de forma geral, as competências dos órgãos do Judiciário, e a partir da função exercida por cada órgão serão estabelecidos os recursos que lhes serão apresentados.

A primeira opção política, então, é traçada na própria Constituição, no momento em que são estabelecidas regras de competência gerais. Não é à toa que o nosso texto constitucional menciona, em diversas passagens, recursos em espécie que serão cabíveis nas situações que especifica. ${ }^{6}$ Isso não retira do legislador ordinário a liberdade para estabelecer outros recursos, além dos previstos constitucionalmente, o que geralmente é feito por meio de leis ordinárias, e em nosso caso, com mais detalhes no Código de Processo Civil.

Esse processo de definição do aparato recursal, longe de ser algo exclusivamente legal, advém de uma deliberação político-legislativa muitas vezes intensa, e que carrega diversas ideologias, muitas vezes não percebidas cotidianamente.

Para Ovídio A. Baptista da Silva, o recurso é a expressão da desconfiança no julgador, e essa desconfiança está sedimentada em um ideal racionalista, que tem no juiz a figura do mero aplicador da lei:

\footnotetext{
${ }^{6}$ Vide os artigos 102, II e 105, II (Recurso Ordinário Constitucional); 102, III e 105, III (Recurso Extraordinário e Especial, respectivamente); 108, II (recurso que impugna a decisão singular de juiz federal).
} 
O princípio imanente que preside o sistema de recursos, idêntico ao que estrutura o Processo de Conhecimento - consequentemente o procedimento ordinário - é o pressuposto de que a lei possua uma "vontade", ou seja, que a proposição legal contenha sentido unívoco, capaz de ser "revelado" (declarado) pelo juiz. A aceitação deste pressuposto é que torna possível legitimar a extraordinária cadeia recursal que ameaça implodir a jurisdição. (SILVA, 2004, p. 243).

Tomando por base tal perspectiva, sendo o juiz o mero aplicador da lei, compete-lhe apenas declarar a sua vontade (a da lei) na decisão, de modo que o recurso é o mecanismo disposto para controlar se essa aplicação da vontade legal foi realizada de forma adequada ou não. Nesse paradigma racionalista, a decisão precisa ser passível de amplo controle, pois o juiz não está legitimado para fundamentar a sua decisão em nada mais do que na vontade da lei, de modo que se ferir esse pressuposto, a sua decisão pode ser revista por outros juízes, que têm mais experiência no conhecimento da vontade legal.

O que se espera de um juiz é que ele descubra, como na solução de uma equação matemática, a vontade da lei, sem que para isso tenha que levar em consideração qualquer aspecto externo à busca, como seus valores morais ou políticos (SILVA, 2004, p. 245). Desse ponto de vista, não é possível tratar de uma decisão justa ou injusta para o caso concreto, mas apenas de uma decisão certa ou errada no ato mecânico de aplicação da lei.

Tal concepção, que remonta historicamente à chamada escola da exegese (BOBBIO, 2006), pressupõe como pano de fundo ideológico não apenas o racionalismo, mas também o liberalismo burguês, na medida em que exige que direitos e obrigações sejam sempre prédeterminados, visto que isso corrobora com a segurança e a previsibilidade que se tornaram a pedra angular das revoluções burguesas e do direito moderno. Assim como o contrato passa naquele momento a ser visto como absoluto, como tendo força de lei (pacta sunt servanda) a própria lei passa a ser vista como algo dotado de um único sentido correto.

Tal racionalismo solapou a concepção clássica do direito como uma prática prudencial, na qual as normas não eram dadas de antemão, mas eram construídas pelo magistrado à luz do caso concreto em um exercício de prudência. O século XIX, momento em que o racionalismo tratado por Ovídio torna-se central, representa justamente o afastamento da antiga concepção de direito como jurisprudentia, sendo substituída pela ideia de que a codificação é clara e capaz de resolver todos os casos que eventualmente apareçam perante o tribunal. Mais ainda, o Juiz é reduzido a ser a mera boca que repete as palavras da lei (Juiz boca da lei), tudo isso sob a premissa (hoje em dia bastante questionável) de que apenas o poder legislativo cria direito (STRECK, 2007). 
Esses, em suma, são os pressupostos ideológicos para a aparelhagem recursal extensa existente no Brasil. Ovídio A. Baptista da Silva aponta os equívocos dessa postura ideológica:

A doutrina, porém, parte de dois pressupostos equivocados. Primeiro, imagina que a lei contenha todo o direito, que, como sustentam as correntes do positivismo moderno, a justiça não seja problema do juiz. A justiça seria um problema do legislador: ou o juiz aplica a lei ou será irremediavelmente injusto (Hobbes). Segundo, como pensamos pela epistemologia do "certo" e do "errado", dizendo que o juiz deve descobrir a "vontade da lei", estaremos pressupondo que possa haver apenas "uma vontade da lei" a ser revelada na sentença. Por força de nosso férreo dogmatismo, não nos é dado admitir que a lei, sendo hermeneuticamente interpretada, possa deixar ao magistrado uma margem de liberdade que lhe permita fazer o Direito progredir, harmonizando-o com as novas realidades sociais e históricas, capazes de revelar, agora, "outra vontade" da lei. (SILVA, 2004, p. 244)

A realidade jurídica aponta para uma mudança no paradigma da atuação jurisdicional. O juiz, longe de ser o mero aplicador da vontade da lei, é o responsável por atribuir-lhe sentido, diante de um caso concreto. Os atos de conhecer, interpretar e aplicar a lei são fundidos num único momento, quando o juiz apresenta a sua decisão para um problema real que lhe foi posto para julgamento. Não é possível ao juiz declarar a vontade da lei, pelo simples fato de a lei não possuir vontade. A vontade é a do interprete, que tem o dever de atribuir o melhor sentido possível à lei, diante solução de um caso concreto. ${ }^{7}$

Afirmar que o juiz tem o papel de aplicar o direito declarando a vontade da lei, através da investigação mecânica desse sentido, significa retirar do juiz o seu elemento mais natural, a sua humanidade. Como humano ${ }^{8}$, compete ao juiz interpretar a lei, não de forma mecânica e isolada, mas dentro do contexto fático no qual ela deva ser aplicada, independentemente de uma sobrenatural vontade que a lei em si tenha, ou mesmo da vontade que o legislador possuía no momento da sua criação. Defender a possibilidade de declaração de uma vontade da lei não é uma premissa ideológica falha, mas sim uma premissa inexistente, visto que é impossível descobrir essa vontade, pois ela não existe.

\footnotetext{
${ }^{7}$ Embora não constitua o foco central do trabalho, é importante mencionar que o paradigma jurídico-ideológico firmado no presente artigo tem por base as idéias de Ronald Dworkin, em especial as proferidas em $O$ Império do Direito (2003), de onde se retira a singular passagem: "Portanto, a exposição construtiva da interpretação criativa talvez pudesse fornecer uma descrição mais geral da interpretação em todas as suas formas. Diríamos, então, que toda interpretação tenta tornar um objeto o melhor possível, como exemplo de algum suposto empreendimento, e que a interpretação só assume formas diferentes em diferentes contextos porque empreendimentos diferentes envolvem diferentes critérios de valor ou de sucesso." (DWORKIN, 2004, p. 65).

${ }^{8}$ É inclusive interessante perceber que, sob os pressupostos da hermenêutica contemporânea, interpretar não é uma escolha, mas a condição inevitável de quem lida com componentes dotados de sentido. Interpretar é, assim, atribuir e não resgatar um sentido (GADAMER, 1999, p. 422).
} 
Sendo assim, o paradigma racionalista que dá base ideológica à amplitude do sistema recursal brasileiro não mais se justifica. Por esse motivo, o aparato recursal brasileiro precisa ser revisto, para se adequar à nova realidade da tutela jurisdicional, calcada numa hermenêutica interpretativa que atribui ao juiz não mais o papel de "declarador do direito", mas sim de responsável pela efetivação dos direitos, mediante a solução das demandas que lhes são postas.

\section{A RESISTÊNCIA DOUTRINÁRIA À LIMITAÇÃo DOS RECURSOS NO PROCESSO CIVIL}

Diante da derrocada do paradigma racionalista, o que justifica a manutenção de um sistema recursal tão complexo como o brasileiro?

O principal argumento que surge em defesa da manutenção do sistema recursal brasileiro, sob o ponto de vista jurídico, é o caráter de princípio basilar do processo que é atribuído ao duplo grau de jurisdição, corolário do princípio geral da segurança jurídica.

Em obra clássica, leciona Nelson Nery Jr:

O princípio do duplo grau de jurisdição tem íntima relação com a preocupação dos ordenamentos jurídicos em evitar a possibilidade de haver abuso por parte do juiz, o que poderia em tese ocorrer se não estivesse a decisão sujeita à revisão por outro órgão do Poder Judiciário. (...)Tendo em vista a falibilidade do ser humano, não seria razoável pretender-se fosse o juiz homem imune de falhas, capaz de decidir de modo definitivo sem que ninguém pudesse questioná-lo em sua fundamentação ao julgar.(...)Além dessas circunstâncias, há ainda o fato de que o juiz único poderia tornar-se despótico, sabedor de que sobre as decisões não haveria controle algum, conforme sábia advertência de Montesquieu. Nesta linha de raciocínio, o princípio do duplo grau e jurisdição é, por assim, dizer, garantia fundamental de boa justiça. (NERY JR, 2004, PP. 37/39).

É forçoso admitir que, por força de uma interpretação do art. $5^{\circ}, \mathrm{LV}$, conjugado com o capítulo que estrutura o Poder Judiciário na Constituição, vislumbre-se a existência do princípio do duplo grau de jurisdição, como garantia de controle das atividades estatais, em especial da atividade jurisdicional (DIDIER JR; CUNHA, 2006, p. 23-24). No entanto, não se pode admitir que, em virtude desse viés constitucional, o duplo grau de jurisdição possa ser observado como um princípio absoluto $^{9}$, que se sobrepõe aos demais princípios constitucionais do processo, de modo a estabelecer que toda decisão judicial seja passível de impugnação.

\footnotetext{
${ }^{9} \mathrm{~A}$ noção de princípio absoluto é inclusive contraditória com a moderna teoria dos princípios, que parte justamente do pressuposto de que sua força varia de acordo com o peso que possuem no caso concreto (DWORKIN, 2007).
} 
Isso porque, como lembra Flávio Cheim Jorge, a própria Constituição Federal estabelece situações de competência originária dos tribunais superiores, em especial do STF, nas quais não será possível apresentar insurgência pela via recursal. ${ }^{10}$ Ademais, quando a Constituição não limita a existência dos recursos, estabelece limites às matérias que poderão ser neles discutidas, o que surge como clara relativização do princípio do duplo grau de jurisdição.

Tais situações fazem-nos concluir que é forçoso demais defender que as partes possam, sempre, recorrer contra toda e qualquer decisão prolatada em juízo, sendo permitido a elas um reexame de toda a matéria. De melhor alvitre se torna entender que a disposição constitucional relativa aos "recursos" $\left[5^{\circ}, \mathrm{LV}, \mathrm{CF}\right]$ deve ser vista em relação ao regular devido processo legal, de modo que não sejam permitidos abusos ou mesmo que se impossibilite às partes o controle das decisões judiciais, garantindo-se assim o direito à ampla defesa. (JORGE, 2009, p. 37).

Luiz Guilherme Marinoni e Sérgio Cruz Arenhart adotam uma posição mais crítica em relação ao princípio do duplo grau de jurisdição, negando o seu caráter constitucional:

$\mathrm{O}$ art. $5^{\circ}, \mathrm{LV}$ da $\mathrm{CF}$ que dizer que o recurso não pode ser suprimido quando inerente à ampla defesa; e não que a previsão do recurso é indispensável para que seja assegurada a ampla defesa em todo e qualquer caso. (...) Em conclusão, é correto afirmar que o legislador infraconstitucional não está obrigado a estabelecer, para toda e qualquer causa, uma dupla revisão em relação ao mérito, principalmente porque a própria Constituição Federal, em seu art. $5^{\circ}$, LXXVIII, garante a todos o direito à tutela jurisdicional tempestiva, direito este que não pode deixar de ser levado em consideração quando se pensa em "garantir" a segurança da parte da através da instituição da dupla revisão. (MARINONI; ARENHART, 2010, pp. 504-507).

Para estes autores, o recurso não é um meio de controle da atividade jurisdicional, mas apenas um meio para viabilizar uma segunda análise da causa posta ao Judiciário. Em sendo assim, é adequado que em algumas situações o legislador opte por não estabelecer essa possibilidade, especialmente diante de causas de menor complexidade.

Em algumas situações, a complexidade do procedimento desenvolvido em primeira instância seria suficiente para justificar a limitação dos recursos, ou mesmo da matéria neles tratada, pois o juiz singular, e somente ele, teria condições de julgar a causa, diante do seu contato próximo com a realidade dos fatos (MARINONI; ARENHART, 2010, p. 505).

\footnotetext{
${ }^{10}$ Vide as ações de controle concentrado de constitucionalidade (102, I, 'a', CF), o Mandado de Segurança contra atos do Presidente da República (102, I, 'd', CF), o Mandado de Injunção quando a elaboração da norma ausente competir ao Congresso Nacional (102, I, 'q', CF).
} 
O princípio do duplo grau de jurisdição, nessa visão, não teria fundamento numa ideia de segurança jurídica, a possibilitar o controle das decisões judiciais, mas sim na ampla defesa, a garantir uma oportunidade de revisão das decisões, e que, portanto, poderia ser relativizada para dar prevalência a outros princípios de índole constitucional, como a razoável duração do processo.

Diante desse panorama doutrinário, observa-se que mesmo o argumento do viés constitucional do princípio do duplo grau de jurisdição deve ceder, em busca de um sistema recursal menos complexo, que privilegie a prestação jurisdicional do juiz singular, em busca de uma tutela mais célere e adequada.

Algumas reformas legislativas foram realizadas no Código de Processo Civil anterior e até na Constituição ${ }^{11}$ referentes ao sistema recursal, mas em sua maioria tiveram impacto nos tribunais superiores, como aponta Ovídio A. Baptista da Silva:

Não deixa de ser sintomático que os legisladores venham, ao longo do tempo, buscando superar a insuportável morosidade da Justiça, através do aprimoramento do sistema recursal — fortalecendo, com essa conduta, ainda mais o principal foco do emperramento processual -, sem jamais preocuparem-se com a causa verdadeira do fenômeno, que reside, certamente, no estilo da função jurisdicional que praticamos, com o consequente menosprezo (...) pela jurisdição de primeiro grau, domínio ignorado pelas reformas (SILVA, 2004, p. 261).

O Código de Processo Civil atual, em vigor desde março de 2016, também operou modificações no sistema recursal, com destaque para a supressão do recurso de embargos infringentes, substituído pelo incidente de "infringência automática" contido no art. 942, e a limitação do cabimento do recurso de agravo de instrumento às hipóteses taxativamente previstas em lei, nos termos do art. 1.015 do CPC. Não obstante, tais mudanças soam tímidas no sentido de fortificação da jurisdição de $1^{\circ}$ grau.

Em sendo assim, faz-se necessário expor os motivos pelos quais a jurisdição de primeiro grau merece maior força, a justificar uma modificação no sistema recursal atual, especificamente nesse ponto, para uma prestação jurisdicional mais adequada.

\section{PROXIMIDADE ENTRE FATO E DIREITO NA ATIVIDADE JURISDICIONAL EM PRIMEIRA INSTÂNCIA}

\footnotetext{
${ }^{11}$ Com destaque para a Emenda Constitucional 45 de 2004, que estabeleceu o instituto da Repercussão Geral para o Recurso Extraordinário $\left(102, \S 3^{\circ}, \mathrm{CF}\right)$ e para as leis 11.418 de 2006 e 11.672 de 2008, que estabeleceram, por meio de reforma no CPC/1973, o procedimento para julgamento de recursos repetitivos perante os tribunais superiores, que já foram incorporados no atual Código de Processo Civil.
} 
Para Ovídio A. Baptista da Silva, "a legitimidade da jurisdição de grau inferior diminui na medida em que aumentam os recursos" (SILVA, 2004, p. 240). Pode-se afirmar, no entanto, que um sistema recursal com uma variedade muito grande de recursos não retira a legitimidade apenas da jurisdição em grau inferior, mas sim de toda a atividade jurisdicional.

Como dito acima, uma consequência natural da interposição de um recurso, seja ela qual for, é tornar a prestação jurisdicional mais demorada. Esse prolongamento da atividade jurisdicional provoca a elevação dos custos do processo, representando denegação de justiça, constituindo um instrumento que beneficia muitas vezes a parte que não tem razão, em detrimento do possuidor do direito, que fica à mercê do tempo, aguardando a reanálise da causa, vendo o seu direito continuar sendo lesado (DIDIER JR; CUNHA, 2006, p. 25).

Esse prolongamento se dá em virtude da desconfiança ideológica sobre a figura do juiz singular, que, segundo o paradigma racionalista, não deve ter o poder de decidir o conflito sozinho, sob risco de não aplicar de forma adequada a vontade a lei. Acontece que, em determinadas circunstâncias, é justamente esse juiz singular o mais preparado para julgar o conflito.

Como é sabido, o procedimento que regula a maioria dos processos civis no Brasil é o procedimento comum, regulamentado a partir do art. 318 do CPC. Esse procedimento, não obstante os esforços no sentido de simplificação, ainda é marcado por uma série de formalidades, que têm fundamento no exercício do contraditório pleno pelas partes, e na cognição exauriente do juiz. Tendo em conta as regras de competência territorial, será o juiz singular o mais próximo da realidade dos fatos que ensejaram o conflito. Cabe a ele a avaliação inicial das alegações das partes, a realização das audiências - momento em que terá contato pessoal com as partes e os advogados -, o deferimento e a determinação das provas a serem produzidas no processo, o que ocorre muitas vezes pela iniciativa do próprio juiz, quando determina a produção das provas de ofício (art. 370 do CPC). Em suma, compete a ele a instrução do processo, a fim de formar uma convicção que leve ao julgamento adequado.

Para determinados casos, esse contato pessoal com a realidade fática do conflito é imprescindível, pois é somente mediante essa proximidade que será possível tomar conhecimento das nuances que levaram a questão ao Judiciário. E essa proximidade, tão necessária, não é observada a partir da seara recursal, pois o contato com as partes é feito por 
meio dos autos do processo, com pouquíssimo espaço para o contato real com os contornos pessoais do litígio. ${ }^{12}$

Se não há limitação para impugnar a decisão desse juiz singular — o mais próximo da realidade de conflito — o seu papel se restringe a decidir a causa por meio de mera opiniã $o^{13}$, que só será válida se confirmada por uma instância superior, prestando uma espécie de jurisdição consultiva. Nas palavras de Luiz Guilherme Marinoni e Sérgio Cruz Arenhart:

Na realidade, se o juiz que preside a instrução e tem contato direto com as partes profere decisão que, para produzir efeitos, necessariamente tem que passar pelo crivo de um colegiado, o juiz singular não é propriamente um julgador, porém mais precisamente um instrutor. Sua decisão pode ser vista, no máximo, como um projeto de única e verdadeira decisão, que é a do tribunal. (MARINONI; ARENHART, 2010, p. 502).

O julgamento realizado pelo tribunal, mediante o contato com os autos do processo, inutiliza parte do procedimento estabelecido em primeira instância, pois retira o valor que o contato pessoal com os sujeitos do processo tem à formação da convicção para o julgamento.

Afirma-se, ainda, que os juízes de segunda instância seriam mais experientes que o juiz de primeiro grau, e por esse motivo haveria a necessidade de controle constante de suas decisões por quem mais conhece do direito. Ora, essa premissa só pode ser verdadeira se afirmada de modo abstrato, mas não em relação ao conflito real posto à apreciação, pois é apenas o contato fático com a causa que é capaz de formar a experiência necessária para apreciação do conflito. Parte, a mesma, da premissa racionalista de separação entre fato e direito, como se fosse possível renunciar a realidade de um conflito para aplicar o direito na sua solução (SILVA, 2004, p. 240).

Afirmar ainda que o juiz, por ter conhecimento de que sua decisão é passível de controle, tomaria decisões mais cautelosas, com maior responsabilidade, é partir do pressuposto de que o juiz de primeira instância está mais fadado a errar do que a acertar em sua decisão. Qualquer sistema jurídico deve depositar nos seus membros a confiança necessária para que atuem de forma adequada, e a criação de um aparato recursal, que parta

\footnotetext{
${ }^{12}$ É necessário estabelecer que, não obstante o CPC preveja a realização de sustentação oral em alguns recursos (art. 937), a prática forense tem demonstrado que a relevância desse ato para a cognição do conflito é relativa, muitas vezes pela falta de interesse dos julgadores em ouvir a argumentação dos advogados, que também, não raras as circunstâncias, se mostram completamente despreparados para exercer a oralidade perante o tribunal.

13 "Dada a ampla possibilidade de submeter a decisão proferida pela primeira instância à apreciação do órgão de segundo grau, a atividade processual daquele viria a reduzir-se apenas à presidência da atividade instrutória e "opiniões" quanto a questões de mérito, as quais só seriam definitivamente resolvidas em segundo grau". (DIDIER JR; CUNHA, 2006, p. 25)
} 
da idéia de que o juiz erra mais que acerta, traz descrédito ao ordenamento processual como um todo.

Nesses termos, o clamor por um processo judicial mais célere - que dê aos jurisdicionados uma resposta em um tempo adequado, apta a viabilizar o exercício efetivo dos seus direitos materiais - requer uma profunda revisão do sistema recursal brasileiro, não apenas quanto à atividade dos tribunais superiores, mas especialmente em relação aos recursos cabíveis para impugnar as decisões proferidas pelos juízes de primeira instância.

\section{CONCLUSÃO: AVANÇAMOS?}

Diante da realidade apresentada, percebe-se que amplitude do sistema recursal brasileiro decorre de uma ideologia racionalista que vê na jurisdição uma atividade mecânica de aplicação da vontade da lei, fazendo surgir diversos meios de controle dessa atividade. Ao juiz compete aplicar a vontade da lei de forma certa ou errada, e por isso são necessários meios para verificação dessa adequada aplicação.

Assim, repensar a sistemática recursal envolve repensar a própria natureza da jurisdição, o que sem dúvida é tarefa complexa. No entanto, a observação de um problema profundo - natureza da jurisdição - não impede que seja observado também um problema mais raso, de ordem pragmática — sistema recursal — para que sejam promovidas alterações pontuais aptas a dar mais efetividade às decisões dos juízes de primeiro grau. Como aponta Ovídio A. Baptista da Silva:

Se ainda não adquirimos uma visão lúcida da necessidade de repensar a natureza da função jurisdicional que o conjunto de determinantes históricas e sociais nos impõe, de modo que se possa resgatar a jurisdição de primeiro grau, com a natural e desejável redução dos recursos — inclusive e especialmente com a limitação do efeito devolutivo da apelação -, então o remédio de que nos podemos valer será atingirmos a causa atacando sua consequência, procedendo a um corte cirúrgico no sistema recursal. (SILVA, 2004, p. 261).

O momento oportuno para a realização do tal corte cirúrgico no sistema recursal ocorreu durante as deliberações legislativas para a aprovação do novo Código de Processo Civil.

Muitas são as questões estiveramem debate no texto do novo CPC. Em relação ao objeto desse trabalho, ganharam destaque as discussões sobre: a diminuição da quantidade de recursos cabíveis a impugnar a decisão do juiz de primeira instância (exclusão do agravo 
retido); a limitação da incidência do agravo de instrumento, a ser utilizado para impugnar apenas algumas espécies de decisões interlocutórias, expressamente previstas em lei; a criação de um sistema de precedentes vinculantes que inviabilize a interposição de recursos quando os precedentes foram devidamente aplicados na solução de um caso concreto pelo juiz singular, dentre outras.

Em relação à diminuição da quantidade de recursos cabíveis a impugnar decisões de primeira instância, de fato observou-se a exclusão do recurso de agravo retido no texto aprovado, a custo, no entanto, da ampliação da devolutividade do recurso de apelação, que poderá atacar também as decisões interlocutórias não impugnáveis por agravo de instrumento, em vista de se tornarem não precluíveis até o momento da apelação $\left(1.009, \S 1^{\circ}, \mathrm{CPC}\right)$.

Quanto ao famigerado efeito suspensivo da apelação, tornou-se um dos pontos mais polêmicos do processo legislativo. A versão inicial aprovada no Senado não previa expressamente a concessão de efeito suspensivo legal para a apelação. ${ }^{14}$ Entretanto, após longas deliberações no Congresso Nacional, com destaque para as discussões na Câmara dos Deputados, prevaleceu o entendimento pela manutenção do efeito suspensivo como regra, nos termos do art. 1.012 do CPC/15.

Por fim, cabe destacar a aprovação da sistemática de vinculação de precedentes no novo Código de Processo Civil, que viabilizará a redução de recursos a longo prazo, caso os juízes de primeira instância observem os precedentes estabelecidos pelos tribunais superiores. A sistemática de vinculação, longe de engessar a atuação do juiz de primeiro grau, dará a este um papel de protagonismo na identificação das razões de decidir dos casos sob sua análise, para a aplicação adequada dos precedentes dos tribunais superiores, ou mesmo para a realização de distinções para os casos concretos.

Em análise primária, pode-se observar um avanço em relação à proposta deste artigo com o novo Código, especialmente com a sistemática de vinculação de precedentes. O que se percebe, em verdade, é que a vinculação dos precedentes, aplicada à ordem jurídica do Brasil, consistirá em importante aperfeiçoamento de nosso sistema jurídico, em busca de igualdade material, segurança jurídica (estabilidade) e previsibilidade, especialmente à tutela dos direitos fundamentais (NOGUEIRA, 2014), desde que empregada de modo adequado, respeitando as peculiaridades históricas e sociais da realidade brasileira, propiciando ao magistrado de primeira instância papel importante na sua aplicação. Em contrapartida, a

\footnotetext{
${ }^{14} \mathrm{O}$ art. 928 do então LPS 166/10 continha a seguinte dicção: “Art. 928. Atribuído efeito suspensivo à apelação, o juiz não poderá inovar no processo; recebida sem efeito suspensivo, o apelado poderá promover, desde logo, a execução provisória da sentença."
} 
manutenção do efeito suspensivo da apelação como regra infirmou a efetividade da decisão do magistrado do primeiro grau.

Não se pode afirmar que atribuir mais força às decisões do juiz de primeira instância seja reflexo do caráter autoritário da jurisdição - essa seria uma visão reducionista do problema. ${ }^{15}$ Tal movimento decorre, antes de tudo, da mudança de paradigma da própria atividade jurisdicional, que tem no juiz a figura do intérprete, apto a dar aos casos concretos a melhor solução possível, através do contato direto com a realidade fática do conflito.

Porém, Só o fato de ter havido debate sobre essas questões já aponta para uma nova realidade. É a conclusão de Ovídio A. Baptista da Silva, que serve de arremate ao presente artigo:

Há sintomas, no entanto, que nos fazem supor que a relação idílica entre os juristas e as promessas da nossa Constituição quanto à irrestrita proteção aos direitos se esteja esgotando, para dar lugar a uma visão mais realista de nossas contingências históricas. Até agora, quando se falava em limitar o número de recursos, como medida indispensável para a celeridade da prestação jurisdicional, a sugestão era logo afastada em nome de superiores princípios constitucionais que asseguravam acesso aos tribunais, com o amplo direito de defesa. Toda limitação que se pretendesse neste campo correria o risco de ser inconstitucional. Pois bem, os ventos já sopram noutro sentido. Tendo advogados quanto juízes começam a propugnar pela redução dos recursos, como um requisito prévio de modernização do sistema. (SILVA, 2004, p. 262).

Nesse contexto, é necessária a reflexão constante sobre as escolhas políticolegislativas que estruturam nosso sistema recursal.

\footnotetext{
${ }^{15}$ Como fez Antônio Cláudio da Costa Machado: "Não se pode subtrair dos demandados — pessoas físicas ou empresas - o legítimo direito de tentar reverter decisões desfavoráveis proferidas por um único magistrado, quase sempre assoberbado e apressado. Eliminar o efeito suspensivo é uma agressão ao princípio do duplo grau de jurisdição, um atentado ao Estado Democrático de Direito. É desejar de fato e de verdade criar o totalitarismo judicial entre nós." (MACHADO, 2013)
} 


\section{REFERÊNCIAS}

BOBBIO, Norberto. O Positivismo Jurídico: Lições de filosofia do direito. São Paulo: Ícone, 2006.

DOWRKIN, Ronald. O Império do Direito. São Paulo: Martins Fontes, 2003.

Uma Questão de Princípios. São Paulo: Martins Fontes, 2001.

Levando os Direitos a Sério. 3 ed.São Paulo: Martins Fontes, 2010.

DIDIER JR, Fredie; CUNHA, Leonardo Carneiro da. Curso de Direito Processual Civil. 5 ed. Salvador: Podivm, 2006. Vol. 3.

GADAMER, Hans Georg. Verdade e Método - traços fundamentais de uma hermenêutica filosófica. Trad. de Flávio Paulo Meurer. Rev. por Enio Paulo Giachini. 3 ed. Rio de Janeiro: Vozes, 1999.

JORGE, Flávio Cheim. Teoria Geral dos Recursos Cíveis. 4 ed. São Paulo, Revista dos Tribunais, 2009.

KELSEN, Hans. Teoria Pura do Direito. Trad. João Batista Machado. $6^{\circ}$ ed. São Paulo: Martins Fontes, 1998

MARINONI, Luiz Guilherme; ARENHART, Sérgio Cruz. Curso de Processo Civil. 8 ed. São Paulo: Revista dos Tribunais, 2010.

NERY JUNIOR, Nelson. Teoria Geral dos Recursos. São Paulo: Revista dos Tribunais: 2004.

NOGUEIRA, Gustavo Santana. Precedentes Vinculantes no Direito Comparado e Brasileiro. 2 ed. Salvador: JusPodivm, 2014.

RODRIGUES NETTO, Nelson. Recursos no Processo Civil. São Paulo: Dialética, 2004.

SILVA, Ovídio A. Baptista da. Processo e Ideologia. O Paradigma Racionalista. Rio de Janeiro: Forense, 2004.

SILVA, Ovídio A. Baptista da; GOMES, Fábio Luiz. Teoria Geral do Processo Civil. 5 ed. São Paulo: Revista dos Tribunais, 2010.

STRECK, Lênio Luiz. Hermenêutica Jurídica E(M) Crise. $7^{\circ}$ ed. Porto Alegre: 2007

UNGER, Robert Mangabeira. The critical legal studies movement. Washington, DC: Library of Congress, 1986 